University of Wollongong

Research Online

Faculty of Engineering and Information

Faculty of Engineering and Information

Sciences - Papers: Part A

Sciences

$1-1-2014$

Influence of isothermal treatment on $\mathrm{MnS}$ and hot ductility in low carbon, low Mn steels

Kristin R. Carpenter

BlueScope Steel, kristinc@uow.edu.au

Chris Killmore

BlueScope Steel

Rian J. Dippenaar

University of Wollongong, rian@uow.edu.au

Follow this and additional works at: https://ro.uow.edu.au/eispapers

Part of the Engineering Commons, and the Science and Technology Studies Commons

Research Online is the open access institutional repository for the University of Wollongong. For further information contact the UOW Library: research-pubs@uow.edu.au 


\title{
Influence of isothermal treatment on MnS and hot ductility in low carbon, low $\mathrm{Mn}$ steels
}

\begin{abstract}
Hot ductility tests were used to determine the hot-cracking susceptibility of two low-carbon, low Mn/S ratio steels and compared with a higher-carbon plain C-Mn steel and a low $\mathrm{C}$, high $\mathrm{Mn} / \mathrm{S}$ ratio steel. Specimens were solution treated at $1623 \mathrm{~K}\left(1350^{\circ} \mathrm{C}\right)$ or in situ melted before cooling at $100 \mathrm{~K} / \mathrm{min}$ to various testing temperatures and strained at $7.5 \times 10-4 \mathrm{~s}-1$, using a Gleeble 3500 Thermomechanical Simulator. The low $\mathrm{C}$, low $\mathrm{Mn} / \mathrm{S}$ steels showed embrittlement from $1073 \mathrm{~K}$ to $1323 \mathrm{~K}\left(800{ }^{\circ} \mathrm{C}\right.$ to $\left.1050{ }^{\circ} \mathrm{C}\right)$ because of precipitation of $\mathrm{MnS}$ at the austenite grain boundaries combined with large grain size. Isothermal holding for 10 minutes at $1273 \mathrm{~K}\left(1000^{\circ} \mathrm{C}\right)$ coarsened the MnS leading to significant improvement in hot ductility. The highercarbon plain C-Mn steel only displayed a narrow trough less than the Ae3 temperature because of intergranular failure occurring along thin films of ferrite at prior austenite boundaries. The low $\mathrm{C}$, high $\mathrm{Mn} / \mathrm{S}$ steel had improved ductility for solution treatment conditions over that of in situ melt conditions because of the grain-refining influence of Ti. The higher $\mathrm{Mn} / \mathrm{S}$ ratio steel yielded significantly better ductility than the low $\mathrm{Mn} / \mathrm{S}$ ratio steels. The low hot ductility of the two low $\mathrm{Mn} / \mathrm{S}$ grades was in disagreement with commercial findings where no cracking susceptibility has been reported. This discrepancy was due to the oversimplification of the thermal history of the hot ductility testing in comparison with commercial production leading to a marked difference in precipitation behavior, whereas laboratory conditions promoted fine sulfide precipitation along the austenite grain boundaries and hence, low ductility.

\section{Disciplines}

Engineering | Science and Technology Studies

\section{Publication Details}

Carpenter, K. R., Killmore, C. R. \& Dippenaar, R. (2014). Influence of isothermal treatment on MnS and hot ductility in low carbon, low Mn steels. Metallurgical and Materials Transactions B: Process Metallurgy and Materials Processing Science, 45 (2), 372-380.
\end{abstract}




\title{
Influence of Isothermal Treatment on MnS and Hot Ductility in Low Carbon, Low Mn Steels
}

\begin{abstract}
KRISTIN R. CARPENTER, CHRIS R. KILLMORE, and RIAN DIPPENAAR
Hot ductility tests were used to determine the hot-cracking susceptibility of two low-carbon, low $\mathrm{Mn} / \mathrm{S}$ ratio steels and compared with a higher-carbon plain C-Mn steel and a low $\mathrm{C}$, high $\mathrm{Mn} / \mathrm{S}$ ratio steel. Specimens were solution treated at $1623 \mathrm{~K}\left(1350{ }^{\circ} \mathrm{C}\right)$ or in situ melted before cooling at $100 \mathrm{~K} / \mathrm{min}$ to various testing temperatures and strained at $7.5 \times 10^{-4} \mathrm{~s}^{-1}$, using a Gleeble 3500 Thermomechanical Simulator. The low $\mathrm{C}$, low $\mathrm{Mn} / \mathrm{S}$ steels showed embrittlement from $1073 \mathrm{~K}$ to $1323 \mathrm{~K}\left(800{ }^{\circ} \mathrm{C}\right.$ to $\left.1050{ }^{\circ} \mathrm{C}\right)$ because of precipitation of $\mathrm{MnS}$ at the austenite grain boundaries combined with large grain size. Isothermal holding for 10 minutes at $1273 \mathrm{~K}$ $\left(1000{ }^{\circ} \mathrm{C}\right)$ coarsened the $\mathrm{MnS}$ leading to significant improvement in hot ductility. The highercarbon plain C-Mn steel only displayed a narrow trough less than the $\mathrm{Ae}_{3}$ temperature because of intergranular failure occurring along thin films of ferrite at prior austenite boundaries. The low C, high $\mathrm{Mn} / \mathrm{S}$ steel had improved ductility for solution treatment conditions over that of in situ melt conditions because of the grain-refining influence of Ti. The higher $\mathrm{Mn} / \mathrm{S}$ ratio steel yielded significantly better ductility than the low $\mathrm{Mn} / \mathrm{S}$ ratio steels. The low hot ductility of the two low $\mathrm{Mn} / \mathrm{S}$ grades was in disagreement with commercial findings where no cracking susceptibility has been reported. This discrepancy was due to the oversimplification of the thermal history of the hot ductility testing in comparison with commercial production leading to a marked difference in precipitation behavior, whereas laboratory conditions promoted fine sulfide precipitation along the austenite grain boundaries and hence, low ductility.
\end{abstract}

DOI: $10.1007 / \mathrm{s} 11663-013-9851-7$

(C) The Minerals, Metals \& Materials Society and ASM International 2013

\section{INTRODUCTION}

TRADITIONALLY, the addition of Mn to steels provides solid solution strengthening, ferrite grain refinement (hardenability agent) and prevents hot shortness by the formation of MnS ${ }^{[1]}$ In hot ductility studies, there has been much emphasis on the effects of $\mathrm{S}$ and the formation of $\mathrm{MnS}$, but less attention has been given to steels with low Mn levels. Cowley and Mintz ${ }^{[2]}$ suggest that lower Mn levels would reduce the depth of the ductility trough by limiting the precipitation of $\mathrm{MnS}$ within grainboundary ferrite bands, which facilitate void formation. However, Mintz and Mohamed ${ }^{[3]}$ also argue that lower Mn levels can reduce hot ductility because of the decrease in the grain-refinement ability of the steel.

For as-cast material, a reduction in ductility is often attributed to the segregation of $\mathrm{S}$ to austenite grain boundaries leading to the precipitation of sulfide particles at the boundaries. These sulfide particles enhance intergranular failure in austenite by encouraging void

KRISTIN R. CARPENTER, Development Metallurgist, Hot Rolled Product Development and CHRIS R. KILLMORE, Product Design Manager, Hot Rolled Product Development, are with BlueScope Steel, Port Kembla Steel Works, Five Islands Rd, Port Kembla, NSW 2505, Australia. Contact e-mail: kristin.carpenter@ bluescopesteel.com RIAN DIPPENAAR, Head of Postgraduate Studies, Higher Degree Research (HDR) Student Coordinator, is with the Faculty of Engineering, School of Mechanical Materials \& Mechatronics, University of Wollongong, Northfields Av., Wollongong, NSW 2522, Australia.

Manuscript submitted January 13, 2013.

Article published online April 23, 2013. formation during grain boundary sliding. ${ }^{[4-8]}$ This mechanism was found to occur in low carbon steels with low $\mathrm{Mn} / \mathrm{S}$ ratios, where precipitation of $\mathrm{MnS}$ at the austenite grain boundaries during cooling to the tensile test temperature caused embrittlement. ${ }^{[9-12]}$ It has also been put forward that $\mathrm{S}$ decreases the binding energy between austenite grain boundaries and the matrix, thus promoting intergranular failure. ${ }^{[9]}$ Sulfide inclusions have been shown to be instrumental in affecting hot ductility, but the exact embrittlement mechanism is not fully understood.

In order to design meaningful laboratory hot tensile tests, it is important to simulate slab-straightening conditions during continuous slab casting as closely as possible. Unfortunately, much of the information in the literature seems to suggest that the effect of S content on hot ductility depends largely on test conditions. Such a conclusion is clearly untenable. For example, because S in steel forms precipitates on cooling, such as $\mathrm{MnS}$, test samples that are reheated to solution treatment temperatures, typically between $1523 \mathrm{~K}$ and $1623 \mathrm{~K}\left(1250^{\circ} \mathrm{C}\right.$ and $1350{ }^{\circ} \mathrm{C}$ ), the degree of dissolution of sulfides determines the amount of sulfur that goes into solution and is subsequently available for re-precipitation as fine sulfides. Accordingly, it is the amount of $\mathrm{S}$ that redissolves, not the total $\mathrm{S}$ content, which is important for controlling the ductility. ${ }^{[4-8,13,14]}$ Consequently, in situ melting, "as-cast conditions" are necessary to incorporate the total $\mathrm{S}$ content and thus avoid misleading results about the influence of $\mathrm{S}$ on hot ductility. ${ }^{[4,5,7,8,13,14]}$ Banks $^{[14]}$ found that low Mn and 
high $\mathrm{S}$ steels, in particular, required in situ solidification test conditions, and hot ductility tests were improved further by incorporating thermal oscillations to better simulate the continuous casting process.

It has been demonstrated that simulating the complex cooling patterns experienced during continuous slab casting affects hot ductility results. ${ }^{[4,10,15-18]}$ For example, Mintz ${ }^{[4,15]}$ and Suzuki ${ }^{[10]}$ both investigated the influence of introducing thermal cycling during cooling to the test temperature, to simulate the thermal oscillation experience by a continuously cast strand from alternating between rolls and water sprays, and both found that ductility was worsened because of increased $\mathrm{Nb}$ precipitation. Research by El-Wazri ${ }^{[16,17]}$ and also by Akhlaghi ${ }^{[18]}$ simulated a thermal history where specimens were melted, cooled at $\sim 10{ }^{\circ} \mathrm{C} / \mathrm{s}$ to a minimum temperature ranging from $973 \mathrm{~K}$ to $1173 \mathrm{~K}$ $\left(700{ }^{\circ} \mathrm{C}\right.$ to $900{ }^{\circ} \mathrm{C}$ ), reheated to temperatures ranging from $1373 \mathrm{~K}$ to $1473 \mathrm{~K}\left(1100{ }^{\circ} \mathrm{C}\right.$ to $\left.1200{ }^{\circ} \mathrm{C}\right)$, then slowly cooled to the unbending temperature ranging from $\sim 1273 \mathrm{~K}$ to $1453 \mathrm{~K}\left(\sim 1000{ }^{\circ} \mathrm{C}\right.$ to $\left.1180{ }^{\circ} \mathrm{C}\right)$, but no cyclic thermal oscillations were introduced to simulate the thermal pattern because of water spray cooling. The hot ductility values of specimens subjected to these thermal simulations were almost always lower than those predicted by isothermal tests. Despite the known influence of a complex cooling history, much of the hot ductility research has been conducted using a simplified procedure consisting of a heat treatment (solution treatment or in situ melting) followed by direct cooling at a fixed rate to the test temperature. While this method usually provides a good indication of the factors affecting the hot ductility trough, results must be validated against commercial experience to avoid erroneous conclusions on the susceptibility of the steels to transverse cracking.

In this research, such simplified simulations for hot ductility testing on low $\mathrm{C}$, low Mn steels were found to greatly misrepresent the grades' propensity for developing transverse cracking, in comparison with plant experience. This discrepancy between hot ductility testing and plant experience, the effect of $\mathrm{Mn} / \mathrm{S}$ ratio on hot ductility, and the possible embrittlement mechanisms because of $\mathrm{S}$, will be discussed.

\section{EXPERIMENTAL}

A Gleeble 3500 thermomechanical simulator (Dynamic Systems Inc., Poestenkill, NY) was used to conduct hot tensile testing of the steels listed in Table I. The steels were produced by BOS steelmaking practice and continuously slab cast into $230-\mathrm{mm}$-thick slabs. The low C, low $\mathrm{Mn}$ steels, $\mathrm{C} 1$ and $\mathrm{C} 2$, had $\mathrm{Mn} / \mathrm{S}$ ratios of 19.1 and 26.4, respectively. Steel $\mathrm{C} 2$ also contained $\mathrm{Nb}$ and $\mathrm{Ti}$ microalloying elements. A plain C-Mn steel, C3, with a higher carbon content and moderate $\mathrm{Mn} / \mathrm{S}$ ratio was included for comparison with the low carbon grades. Steel C4 is a conventional HSLA steel with high $\mathrm{Mn} / \mathrm{S}$ ratio and microalloyed with $\mathrm{Nb}$ and $\mathrm{Ti}$.

Samples were either melted in situ or solution treated at $1623 \mathrm{~K}\left(1350{ }^{\circ} \mathrm{C}\right)$ and cooled at $100 \mathrm{~K} / \mathrm{min}$ to the test temperature. Samples were held for 1 minute at the test temperature and then strained to failure at a rate of approximately $7.5 \times 10^{-4} \mathrm{~s}^{-1}$, followed by a water quench. The thermomechanical cycle is schematically illustrated in Figure 1. In addition to the above cycles, several samples were subjected to the same cycle except those held isothermally at $1273 \mathrm{~K}\left(1000{ }^{\circ} \mathrm{C}\right)$ for $10 \mathrm{~min}$ utes before straining. The above time and temperature represent the approximate time taken for a strand to reach the unbending segment for typical continuous casting conditions at BlueScope Steel.

In order to compensate for shrinkage during solidification, a compressive deformation of about 7 pet was applied, while the samples were being cooled at $6 \mathrm{~K} / \mathrm{s}$ from the melting temperature down to $1643 \mathrm{~K}$ $\left(1370{ }^{\circ} \mathrm{C}\right)$. Quartz tubes with a diametrical clearance of $0.2 \mathrm{~mm}$ were used to contain the molten zone.

Metallographic examinations were carried out on longitudinal sections taken close to the point of fracture. Fracture surfaces were examined with a Leica Stereoscan 440 (Leica Microsystems Pty Ltd, Wetzlar, Germany) scanning electron microscope (SEM), located at the University of Wollongong. Transmission Electron Microscopy (TEM) was performed at $200 \mathrm{kV}$ on a Joel Scanning Transmission Electron Microscope (Joel, Tokyo, Japan). Electron Probe Micro Analyses, EPMA, was conducted using a Cameca SX-50 (Cameca SAS, Gennevilliers Cedex, France), at BlueScope Steel, Port Kembla, on selected specimens. EPMA Probe settings, featuring high probe currents, are listed in Table II.

\section{RESULTS}

\section{A. Hot Ductility}

The hot ductility shown as percentage of reduction of area (Pct RA) as a function of test temperature is shown in Figure 2 for the solution treatment tests. The $\mathrm{Ae}_{3}$ temperature, included in Figures 2 and 3, was calculated using Andrew's formulae. ${ }^{[19]}$ As seen in Figure 2, steel $\mathrm{C} 3$ showed a narrow trough starting at the $\mathrm{Ae}_{3}$, steel C4 had good ductility at all temperatures, and steels $\mathrm{C} 1$ and $\mathrm{C} 2$ displayed low ductility at all test temperatures. In most cases, ductility improved at $1023 \mathrm{~K}\left(750^{\circ} \mathrm{C}\right)$.

For specimens that were melted in situ, much lower ductility values were recorded as shown in Figure 3. All specimens showed low to very low ductility over a wide temperature range, except for $\mathrm{C} 3$, which had a deep, narrow trough, similar to that observed for solution treatment conditions. In steel $\mathrm{C} 4$, ductility only began to improve at $1273 \mathrm{~K}\left(1000{ }^{\circ} \mathrm{C}\right)$, while for steel $\mathrm{C} 2$, ductility did not improve significantly until $1323 \mathrm{~K}$ $\left(1050^{\circ} \mathrm{C}\right)$. At lower temperatures, ductility began improving at $1023 \mathrm{~K}\left(750^{\circ} \mathrm{C}\right)$ for all steel grades, except C4.

\section{B. Optical Metallography}

Figure 4(a) shows an example of thin films of ferrite forming at austenite grain boundaries, for Steel C3 tested at $1073 \mathrm{~K}\left(800{ }^{\circ} \mathrm{C}\right)$ (below the $\mathrm{Ae}_{3}$ Temperature). 
Table I. Chemical Compositions of Steels Used in Hot Ductility Testing (Weight Percentage)

\begin{tabular}{llllllllrr}
\hline Steel & \multicolumn{1}{c}{ Type } & $\mathrm{C}$ & $\mathrm{Mn}$ & $\mathrm{S}$ & $\mathrm{Mn} / \mathrm{S}$ & $\mathrm{Al}$ (tot) & $\mathrm{N}$ & $\mathrm{Nb}$ & $\mathrm{Ti}$ \\
\hline $\mathrm{C} 1$ & 1006 & 0.055 & 0.21 & 0.011 & 19.1 & 0.032 & 0.0045 & - & - \\
$\mathrm{C} 2$ & $1008+\mathrm{Nb}+\mathrm{Ti}$ & 0.075 & 0.29 & 0.011 & 26.4 & 0.028 & 0.0031 & 0.017 & 0.01 \\
$\mathrm{C3}$ & 1016 & 0.165 & 0.63 & 0.012 & 52.5 & 0.031 & 0.0021 & - & - \\
$\mathrm{C} 4$ & HSLA & 0.08 & 1.39 & 0.001 & 1390 & 0.021 & 0.0046 & 0.044 & 0.018 \\
\hline
\end{tabular}

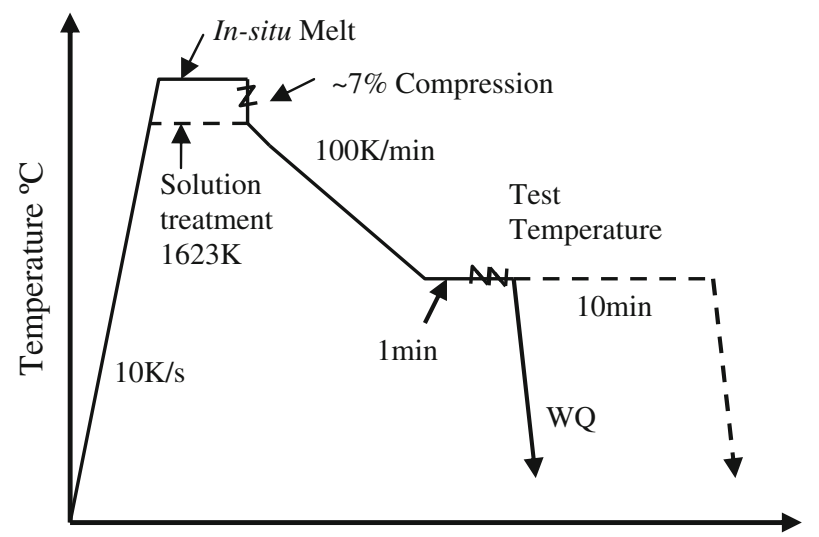

Time (s)

Fig. 1-Schematically illustrated thermomechanical cycle for Gleeble test schedule, including 10-min isothermal hold test.

Table II. EPMA Probe Settings for Mapping of Steel C1

\begin{tabular}{lccccc}
\hline $\begin{array}{l}\text { Figure } \\
\text { No. }\end{array}$ & $\begin{array}{c}\text { Size } \\
(\mu \mathrm{m})\end{array}$ & $\begin{array}{c}\text { Current } \\
(\mathrm{na})\end{array}$ & $\mathrm{kV}$ & $\begin{array}{c}\text { Pixel } \\
(\mu \mathrm{m})\end{array}$ & $\begin{array}{c}\text { Dwell } \\
(\mathrm{ms})\end{array}$ \\
\hline 6 & 100 & 100 & 20 & 0.38 & 100 \\
7 & 100 & 300 & 20 & 0.38 & 100 \\
8 & 512 & 1000 & 20 & 2.0 & 40 \\
9 & 500 & 1000 & 20 & 2.0 & 40 \\
10 & 100 & 1000 & 20 & 0.38 & 100 \\
\hline
\end{tabular}

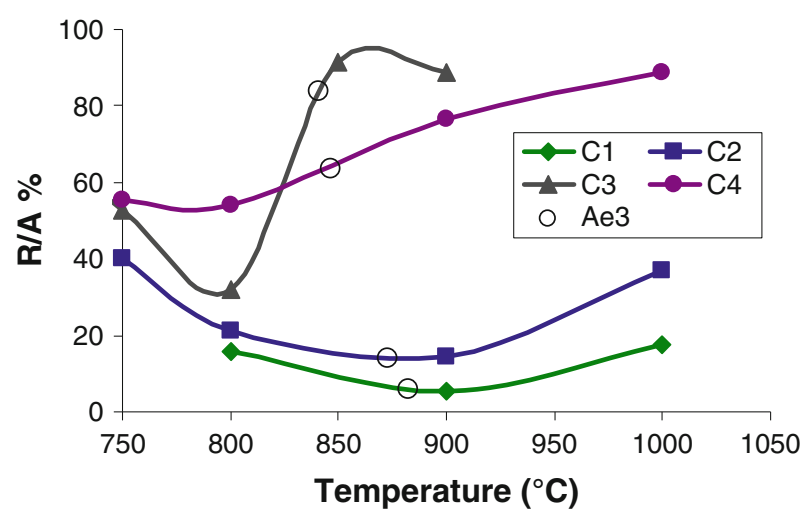

Fig. 2-Hot ductility as a function of test temperature for solution treatment tests, where the $\mathrm{Ae}_{3}$ temperature calculated from the composition is included.

Figure 4(b) shows intergranular cracking in single-phase austenite in steel $\mathrm{C} 2$, which was solution treated and tested at $1173 \mathrm{~K}\left(900{ }^{\circ} \mathrm{C}\right)$.

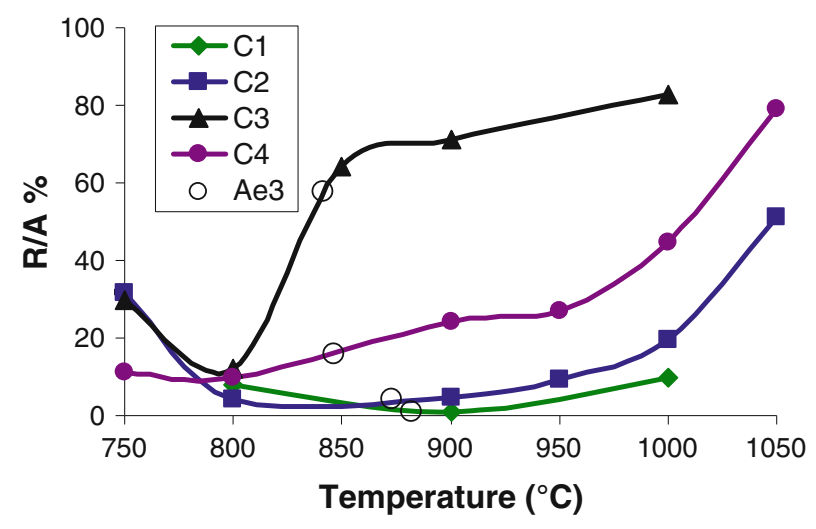

Fig. 3- Hot ductility as a function of test temperature for in situ melt tests, where the $\mathrm{Ae}_{3}$ temperature calculated from the composition is included.

\section{Scanning Electron Microscopy}

The fracture surface of a specimen of Steel 3, which was solution treated and tested at $1073 \mathrm{~K}\left(800{ }^{\circ} \mathrm{C}\right)$, is shown in Figure 5(a), which reveals microvoid coalescence, as evidenced by the dimpled intragranular fracture surface. The fracture surfaces of Steels $\mathrm{C} 1$ and $\mathrm{C} 2$, when tested in the single-phase austenite field, exhibited coarse grain structures and intergranular failure exhibiting smooth, featureless fracture surfaces, Figures 5(b) through (d).

\section{Electron Probe Micro Analysis}

EPMA mapping for $\mathrm{Al}, \mathrm{Mn}$, and $\mathrm{S}$ was carried out on the $\mathrm{C} 1$ grade, and the results are shown in Figures 6 and 7 for tests without isothermal holding, and Figures 8 through 10 for tests with isothermal holding, in both the solution treatment and in situ melting conditions.

\section{DISCUSSION}

\section{A. Solution Treatment Conditions}

The relatively high values of hot ductility at $1023 \mathrm{~K}$ $\left(750{ }^{\circ} \mathrm{C}\right)$ for specimens that were solution treated are attributed to the increased volume fraction of ferrite that forms at this temperature relative to higher testing temperatures. Steel C4 showed significantly better ductility compared with steels $\mathrm{C} 1$ and $\mathrm{C} 2$, which was attributed to finer austenite grain size $(-200 \mu \mathrm{m}$ compared with $\sim 500 \mu \mathrm{m})$ and the lower sulfur content, both of which strongly favor improved ductility. ${ }^{[3,4,6-8]}$ The finer grain size observed was due to the high 

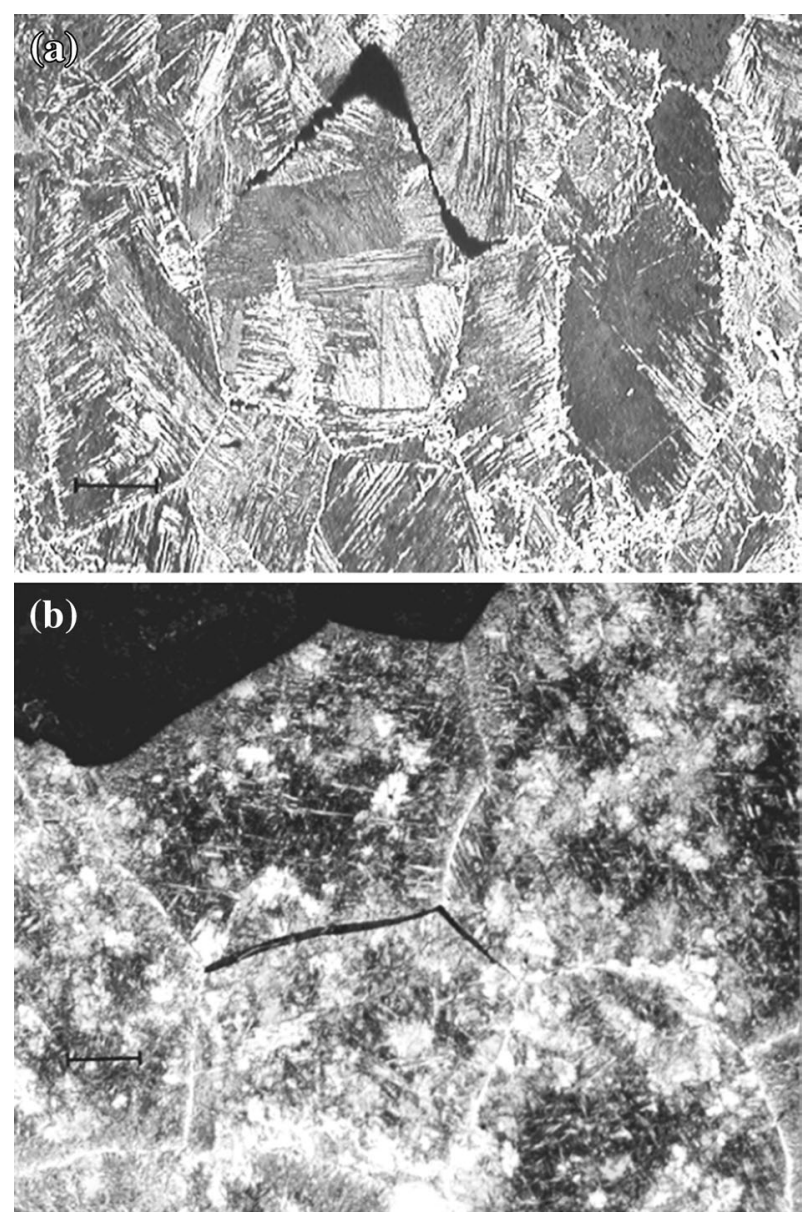

Fig. 4 - (a) Steel C3: Optical micrograph reveals cracking, ostensibly within ferrite that formed on prior austenite grain boundaries. The specimen was solution treated and tested at $1073 \mathrm{~K}\left(800^{\circ} \mathrm{C}\right) .(b)$ Steel $\mathrm{C} 1$ displays severe cracking along prior austenite grain boundaries. The specimen was solution treated and tested at $1173 \mathrm{~K}$ $\left(900{ }^{\circ} \mathrm{C}\right)$. (Micron bar scale: $\left.380 \mu \mathrm{m}\right)$.

microalloying content restricting grain growth at the solution treatment temperature.

Coarse grains are well known to generate low ductility. In general, hot ductility improves with decreasing grain size as finer grains restrict the propagation of small cracks formed by grain boundary sliding at triple points; reduces the crack aspect ratio, which controls the stress concentration at the crack tip and thereby discourages crack propagation; increases the specific grain boundary area for a given volume fraction of precipitate, resulting in a decrease in the precipitation density on the grain boundary and increase in the number of grain boundary nucleation sites, thereby reducing the critical strain for dynamic recrystallization, which can improve the ductility via grain boundary migration. ${ }^{[4,20]}$

Steel $\mathrm{C} 3$ exhibited a narrow ductility trough, between $1023 \mathrm{~K}\left(750{ }^{\circ} \mathrm{C}\right)$ and the $\mathrm{Ae}_{3}$ temperature. Such behavior is conventionally explained because of transformation-controlled intergranular failure, where failure occurs within the thin films of ferrite that form at the prior austenite grain boundaries. ${ }^{[2-4,13]}$ Strain is concentrated at the softer ferrite films, typically leading to failure via voiding around particles or inclusions, such as MnS, present at the austenite grain boundaries. Microstructural observations indicate that transformationcontrolled intergranular failure has occurred. In Figure 4(a), microstructural observations of the fracture region taken in the longitudinal direction revealed microvoid formation and cracking at thin films of grain boundary ferrite. The fracture surface, Figure 5(a), showed that the fracture mode was intergranular and the shallow dimples appeared on the fracture facets, suggestive of ductile microvoid coalescence..$^{[3,4,13,21-23]}$

Steels $\mathrm{C} 1$ and $\mathrm{C} 2$ had very low ductility extending well into the single-phase austenite temperature region. Low ductility in the single-phase austenite temperature region is almost always due to intergranular failure at the austenite grain boundaries. It is generally accepted that cracks are initiated at austenite grain boundaries by the grain boundary sliding mechanism. ${ }^{[3,4,13,22,23]}$

Severe cracking at austenite grain boundaries were observed by Optical Metallography in Steels C1 and C2, and a typical example of such cracking is shown in Figure 4(b) for Steel $\mathrm{C} 1$, tested at $1173 \mathrm{~K}\left(900{ }^{\circ} \mathrm{C}\right)$. Figures 5(b) and (c) showed SEM images that revealed smooth, featureless intergranular fracture surfaces indicative of intergranular failure via grain boundary sliding in austenite. Grain boundary sliding is promoted by slow strain rates, large grain size, and fine precipitation. $^{[3,4,7,13]}$ The large grain size, as measured optically, was also readily observable in the SEM images and contributed to the low hot ductility. Coarse austenite grains can be detrimental to ductility because cracks due to grain boundary sliding can readily propagate along grain boundaries as there are few triple points to arrest crack propagation. Precipitation enhances crack formation via grain boundary sliding by providing crack initiation sites. The role of $\mathrm{S}$ on the failure mechanism will be discussed at a later stage.

\section{B. In Situ Melt Conditions}

The hot ductility curves for the in situ melt tests are shown in Figure 3. When melted in situ, Steel C3 displayed a slightly deeper ductility trough than when it was solution treated. The larger austenite grain size resulting from in situ melting seems to account for this observation.

Steel C4 showed a marked difference in behavior when it was melted and resolidified before testing: a deep, wide trough was observed. The importance of using in situ melting conditions for Ti-bearing steels was illustrated by steel C4. The grain-refinement ability of this steel was lost when microalloying particles were dissolved during melting and a significantly larger grain size (up to $\sim 1 \mathrm{~mm}$ ) was obtained during subsequent re-solidification and cooling. This large grain size contributed significantly to the lower ductility of Steel C4 in the in situ treated condition. Carbon extraction replicas were prepared from in situ melted specimens tested at $1273 \mathrm{~K}\left(1000{ }^{\circ} \mathrm{C}\right)$. Nb-Ti particles less than $10 \mathrm{~nm}$ were identified and were often present in small clusters. The enhancement of grainboundary sliding due to fine, microalloying precipitation is a well-known phenomenon. 

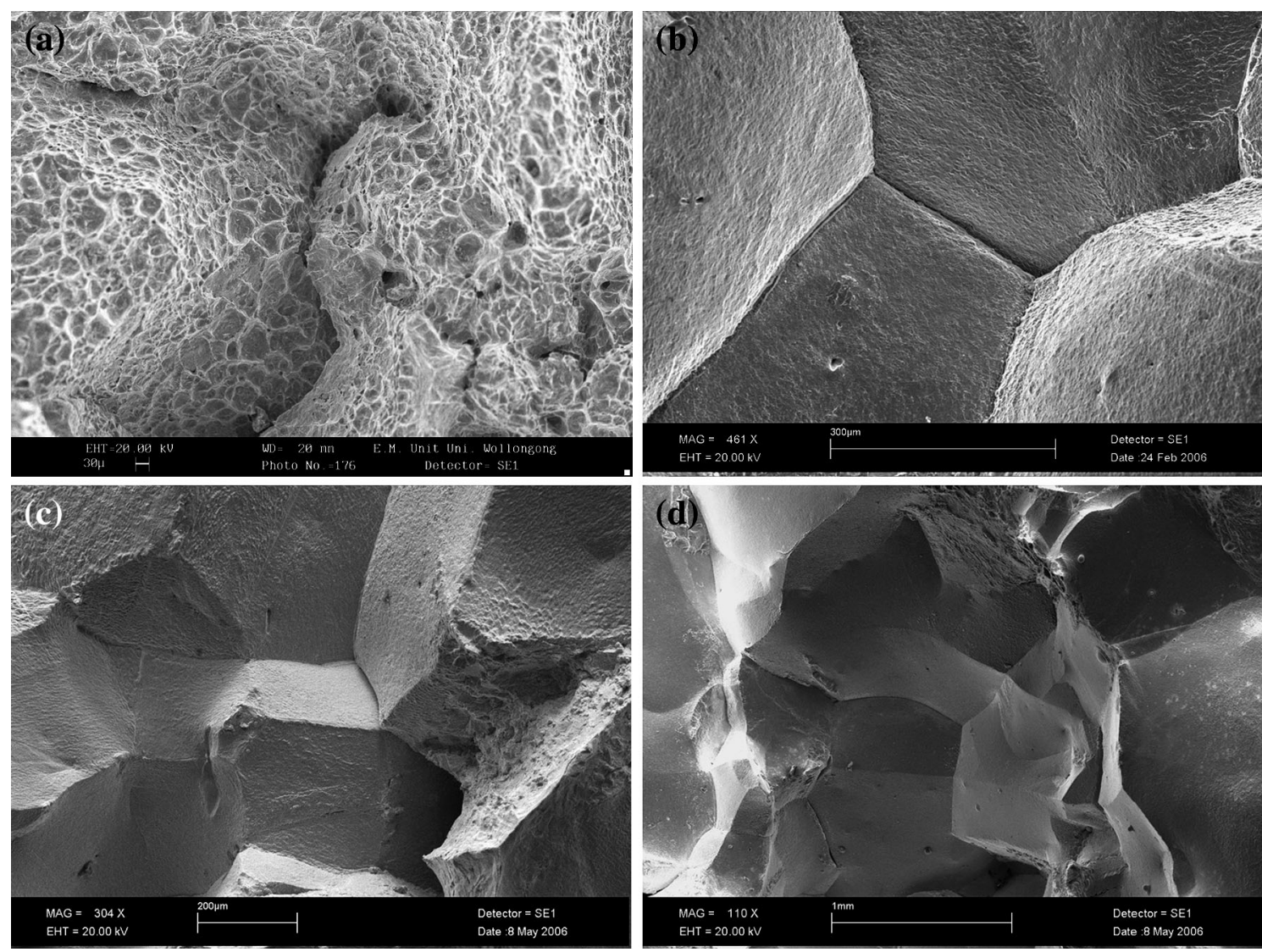

Fig. 5-SEM images of the fracture surface of $(a)$ Steel C3, solution treated and tested at $1073 \mathrm{~K}\left(800{ }^{\circ} \mathrm{C}\right)$, (b) Steel C2, solution treated and tested at $1173 \mathrm{~K}\left(900{ }^{\circ} \mathrm{C}\right),(c)$ Steel $\mathrm{C}$, solution treated and tested at $1273 \mathrm{~K}\left(1000{ }^{\circ} \mathrm{C}\right)$ and $(d)$ Steel $\mathrm{C} 1$, melted in-situ and tested at $1273 \mathrm{~K}$ $\left(1000{ }^{\circ} \mathrm{C}\right)$.
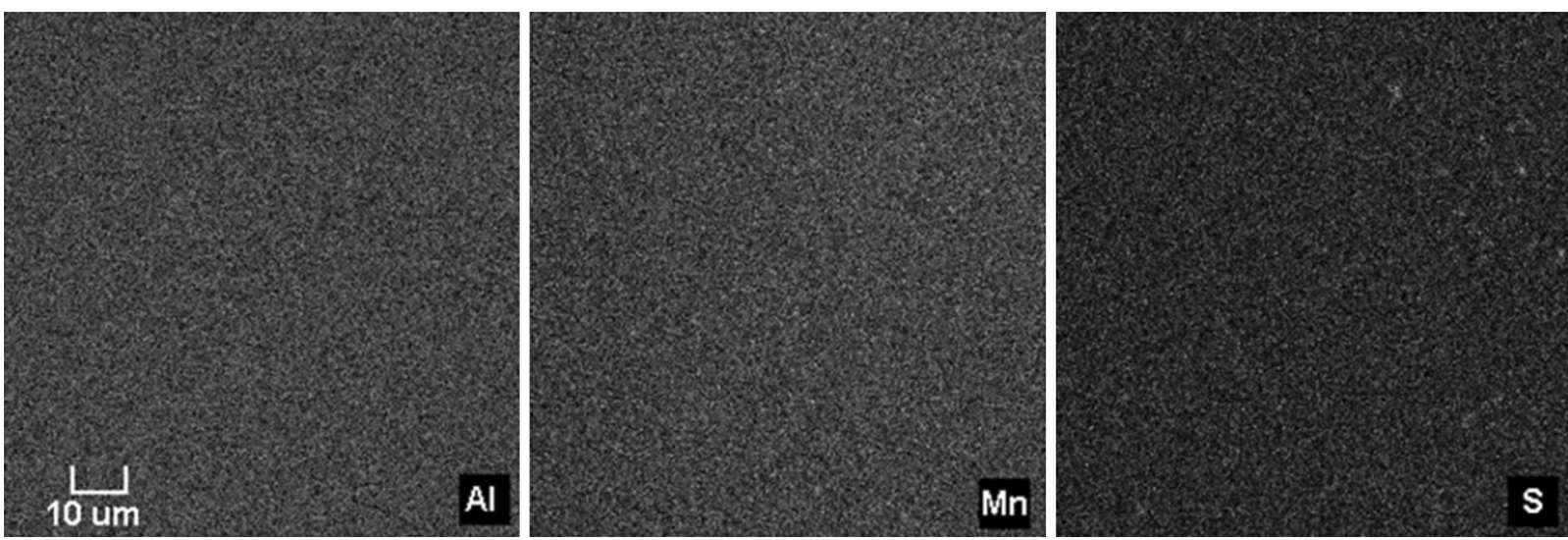

Fig. 6-EPMA image: $\mathrm{C} 1$ solution treatment at $1623 \mathrm{~K}\left(1350{ }^{\circ} \mathrm{C}\right)$, held for $1 \mathrm{~min}$ at $1273 \mathrm{~K}\left(1000{ }^{\circ} \mathrm{C}\right)$, and then quenched.

Steels $\mathrm{C} 1$ and $\mathrm{C} 2$ showed very low ductility at all test temperatures in both the solution treated and in situ melted conditions. From Figures 5(c) and 5(d) it can be observed that both test conditions yielded featureless, intergranular fracture surfaces, and a coarse prior austenite grain size, typical of failure via grain boundary sliding. ${ }^{[3,13,23]}$ Coarse grains are well known to generate low ductility as previously discussed.

\section{Isothermal Holding Tests}

The low ductility of steels $\mathrm{C} 1$ and $\mathrm{C} 2$ was a concern because commercial experience has found that there are no ductility issues for these steels during continuous casting. Several solution treatment and in situ melt tests were conducted for steel $\mathrm{Cl}$ with an isothermal hold at $1273 \mathrm{~K}\left(1000{ }^{\circ} \mathrm{C}\right)$ for 10 minutes, before straining. 
The subsequent tensile test results showed dramatic improvements in ductility; 67.6 and 60.7 pct for solution treated and in situ melt test conditions, respectively. In agreement with earlier findings by Gao and Sorimach$\mathrm{i}^{[24]}$ the significant recovery of ductility was attributed to fine grain boundary $\mathrm{MnS}$ particles coarsening to the point where they no longer influence ductility. EPMA was carried out on samples subjected to the isothermal hold schedule, but quenched before deformation, to investigate the behavior of $\mathrm{Mn}$ and $\mathrm{S}$.

\section{EPMA Analyses}

Owing to similarities in the $\mathrm{Mn}$ and $\mathrm{S}$ content of Steels $\mathrm{C} 1$ and C2, EPMA mapping for A1, Mn, and S was conducted only for $\mathrm{C} 1$, and the results are shown in Figures 6 through 10. EPMA tests on samples without any isothermal holding, Figures 6 and 7, reveal very little evidence of $\mathrm{MnS}$ inclusions, within the limitations of EPMA $(<100 \mathrm{~nm})$. However, for tests with the isothermal hold, Figures 8 through 10, grain-boundary networks of coarsened $\mathrm{MnS}$ particles were evident, leading to $\mathrm{Mn}$ and $\mathrm{S}$ depletions at the prior austenite grain boundaries. The relative absence of $\mathrm{MnS}$ precipitation in the specimens quenched 1 minute after reaching $1273 \mathrm{~K}\left(1000{ }^{\circ} \mathrm{C}\right)$ either means that $\mathrm{MnS}$ particles were too fine $(<100 \mathrm{~nm})$ to be resolved by EPMA or the $\mathrm{Mn}$ and $\mathrm{S}$ were still in solution. The low ductility indicates the former, which again, agrees with Goa and Sorimachi. ${ }^{[24]}$

The EPMA maps showed a network of $\mathrm{S}$ segregation within the matrix for the samples isothermally held. The influence of this network on hot ductility was not understood. Further study is required to clarify the formation and influence of this network.

\section{E. Role of Sulfur on Hot Ductility}

It has been established that $\mathrm{S}$ had a detrimental effect on ductility for the given experimental conditions (solution treatment and in situ melting), for steels C1 and $\mathrm{C} 2$. Since it is the amount of $\mathrm{S}$ that redissolves during solution treatment, which influences hot ductility, rather than the total $\mathrm{S}$ content, it is important to establish the amount of $\mathrm{S}$ that can be redissolved at $1623 \mathrm{~K}\left(1350{ }^{\circ} \mathrm{C}\right)$. Turkdogan ${ }^{[25]}$ demonstrated that the solubility of $\mathrm{S}$ in austenite increases as the $\mathrm{Mn}$ addition decreases because of the effect of $\mathrm{Mn}$ on the activity coefficient of sulfur.

The solubility of $\mathrm{MnS}$ in austenite at a given temperature can be determined by solving the solubility product, $k_{\mathrm{s}}$, of $\mathrm{MnS}$ (Eq. [1]), by using the solubility product of $\mathrm{S}$ (Eq. [2]), and its activity coefficient as a function of temperature (Eq. [3]). ${ }^{[1]}$

$$
\begin{gathered}
k_{\mathrm{S}}=[\mathrm{Mn}][\mathrm{S}] f_{\mathrm{S}}^{\mathrm{Mn}} \\
\log k_{S}=2.929-9020 / T \\
\log f_{\mathrm{S}}^{\mathrm{Mn}}=[0.097-215 / T][\mathrm{Mn}]
\end{gathered}
$$

where $[\mathrm{Mn}]$ is the dissolved $\mathrm{Mn}$ content (wt pct), $[\mathrm{S}]$ is the dissolved $\mathrm{S}$ content (wt pct), $f_{S}^{M n}$ is the effect of $\mathrm{Mn}$ on the activity coefficient of $\mathrm{S}$ in austenite, and $T$ is the temperature (Kelvin). Using the above equations, the solubility of $\mathrm{S}$ at $1623 \mathrm{~K}\left(1350{ }^{\circ} \mathrm{C}\right)$ for steel $\mathrm{C} 1$ was 0.012 pct and for steel $\mathrm{C} 2,0.008$ pct. Owing to the low $\mathrm{Mn}$ content, the $\mathrm{S}$ solubility at $1623 \mathrm{~K}\left(1350{ }^{\circ} \mathrm{C}\right)$ was similar to the total $\mathrm{S}$ contents of steels $\mathrm{C} 1$ and $\mathrm{C} 2$ and therefore the behavior due to $\mathrm{S}$ would be expected to be similar for both test conditions, as the test results imply. The higher Mn level of steel $\mathrm{C} 4$ reduces the solubility of $\mathrm{S}$ at $1623 \mathrm{~K}\left(1350{ }^{\circ} \mathrm{C}\right)$ to only $0.0018 \mathrm{pct}$, which is similar to the total $\mathrm{S}$ level in the steel, but very little influence would be expected from such a low S content on hot ductility.

The embrittlement of low carbon steels with low $\mathrm{Mn} / \mathrm{S}$ ratios due to the precipitation of $\mathrm{MnS}$ at the austenite grain boundaries during cooling to the test temperature is a known phenomenon. ${ }^{[9-11]}$ Low carbon steels with similar $\mathrm{Mn} / \mathrm{S}$ ratios (15 and 30) to steel $\mathrm{Cl}$ (19.1) were tested by Suzuki et al., ${ }^{[10]}$ and low ductility was observed between $1123 \mathrm{~K}$ and $1423 \mathrm{~K}\left(850{ }^{\circ} \mathrm{C}\right.$ to $1150{ }^{\circ} \mathrm{C}$ ), a similar range as observed for this study. Low ductility was attributed to precipitation of $\mathrm{MnS}$ at austenite grain boundaries. A significant increase in the carbon content and higher $\mathrm{Mn} / \mathrm{S}$ ratio (52.5) of steel $\mathrm{C} 3$ appears to inhibit the precipitation of $\mathrm{MnS}$ at austenite grain boundaries as indicated by the excellent ductility observed above the $\mathrm{Ae}_{3}$ temperature.

\section{F. Commercial Findings}

Steels $\mathrm{C} 1$ and $\mathrm{C} 2$ both showed very low ductility at and above $1273 \mathrm{~K}\left(1000{ }^{\circ} \mathrm{C}\right)$ for solution treatment and in situ melt conditions; this indicates a high likelihood for developing transverse cracks during continuous slab casting. As discussed previously, a combination of large grain size and segregation of $\mathrm{S}$ to the austenite grain boundaries resulted in this low ductility. Plant experience reveals that there is no issue with cracking in these grades. ${ }^{[26]}$ Results indicate that the given test conditions promoted the segregation of $\mathrm{Mn}$ and $\mathrm{S}$ to austenite grain boundaries, where on cooling, the decreasing solubility of $\mathrm{S}$ induced fine precipitation of $\mathrm{MnS}$ at austenite grain boundaries, contributing to the very low ductility observed.

This discrepancy with commercial experience is explained because of the oversimplification of the thermal history of a continuously cast slab. From modeling data of the surface temperature of steel $\mathrm{C} 1$ during continuous casting, key points of the thermal history are outlined: the surface temperature drops rapidly after exiting the mold at approximately $500 \mathrm{~K} /$ min to $1293 \mathrm{~K}\left(1050{ }^{\circ} \mathrm{C}\right)$; the slab is then cooled slowly to the unbending segment, taking approximately 9 minutes and the temperature decreases to $1153 \mathrm{~K}\left(880{ }^{\circ} \mathrm{C}\right)$ and during this cooling period thermal oscillations take place, where rapid cooling $\left[\sim 273 \mathrm{~K}\left(\sim 100{ }^{\circ} \mathrm{C}\right)\right]$ and reheating occurred in the roll bite. ${ }^{[26]}$ The rapid cooling would limit segregation to the austenite grain boundaries and the slow cooling afterward would coarsen any $\mathrm{MnS}$ at prior austenite boundaries, diminishing their 

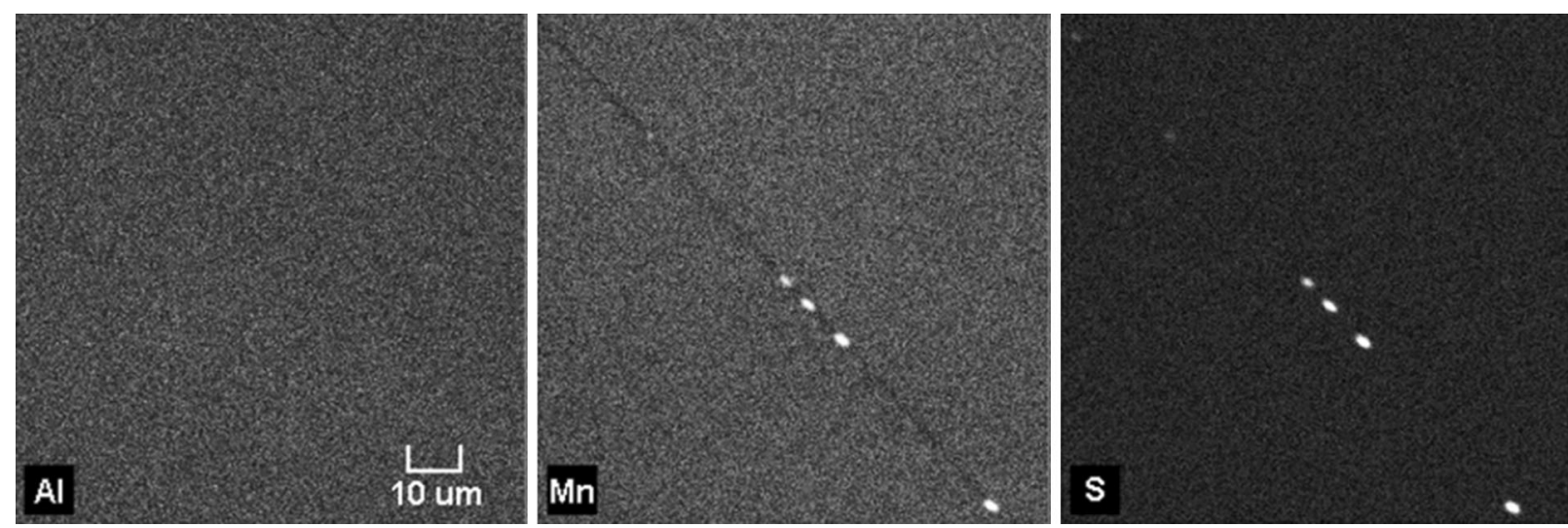

Fig. 7-EPMA image: $\mathrm{C} 1$ in situ Melt condition, held for $1 \mathrm{~min}$ at $1273 \mathrm{~K}\left(1000{ }^{\circ} \mathrm{C}\right)$, and then quenched.
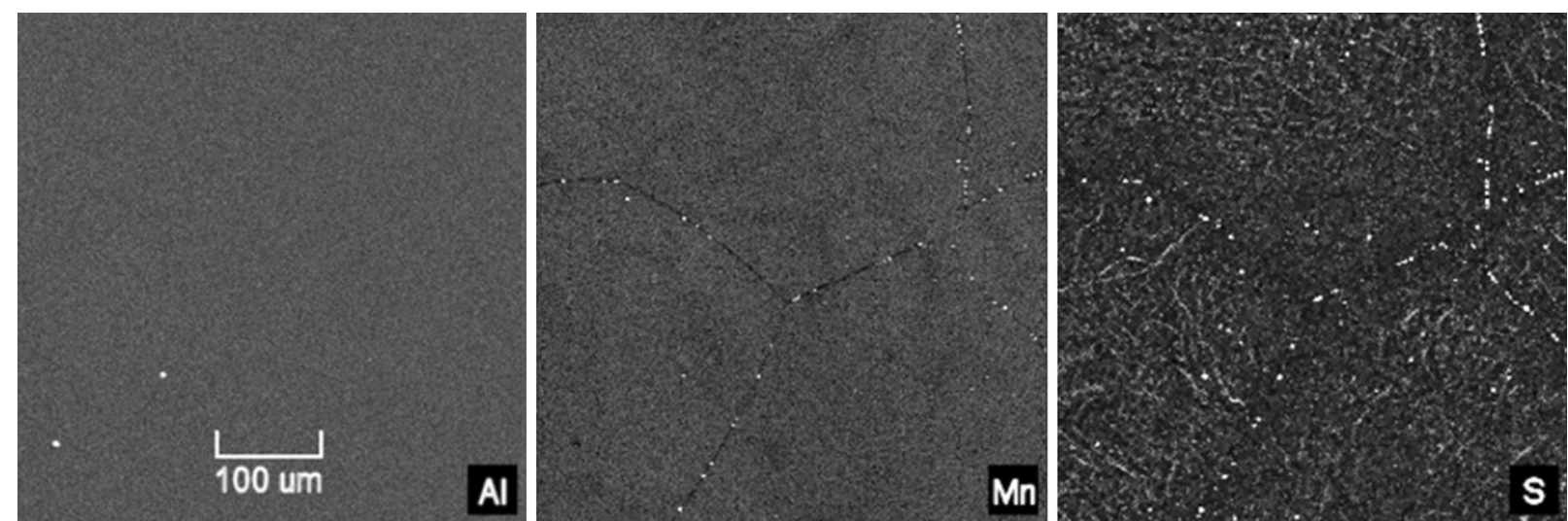

Fig. 8-EPMA image: $\mathrm{C} 1$ solution treatment at $1623 \mathrm{~K}\left(1350^{\circ} \mathrm{C}\right)$, held for $10 \mathrm{~min}$ at $1273 \mathrm{~K}\left(1000^{\circ} \mathrm{C}\right)$, and then quenched.
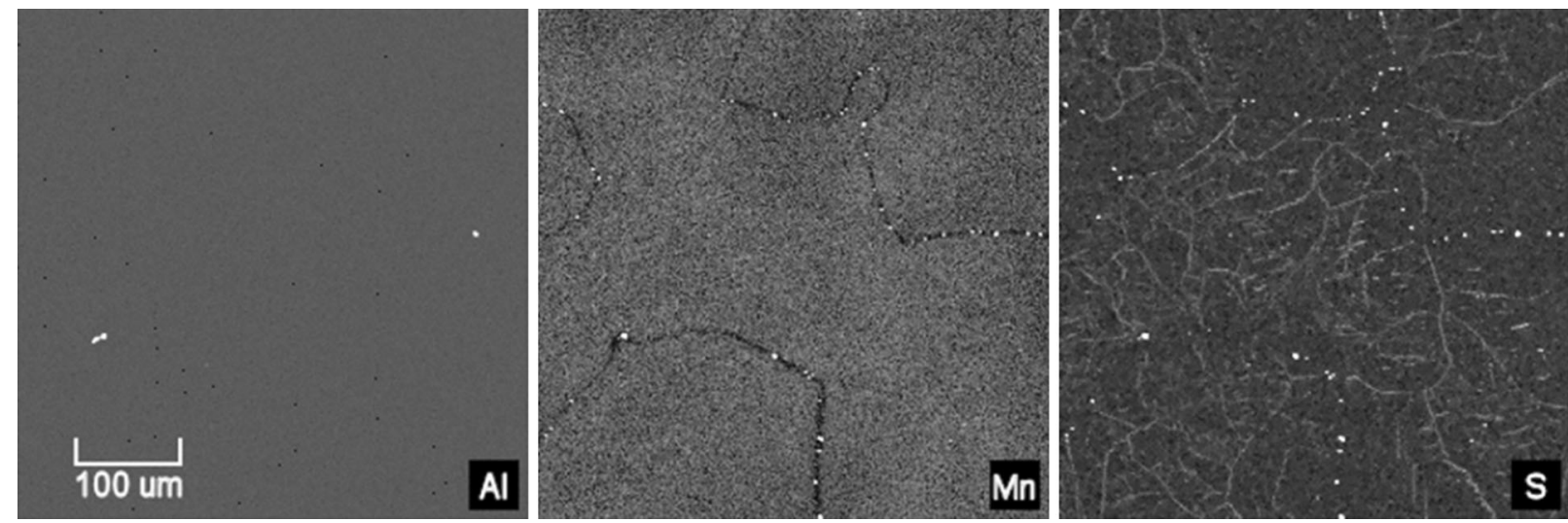

Fig. 9-EPMA image: $\mathrm{C} 1$ in situ Melt condition, held for $10 \mathrm{~min}$ at $1273 \mathrm{~K}\left(1000{ }^{\circ} \mathrm{C}\right)$, and then quenched.

influence on hot ductility. The isothermal holding tests showed a dramatic improvement in ductility because of the coarsening of the MnS at austenite boundaries. The longer hold time more appropriately reflects the longer time taken for a slab to cool to the unbending temperature in practice, which agrees well with the absence of ductility issues observed in commercial experience.

Second, the solidification, segregation pattern, and thermal histories in a large slab cannot be reproduced in a small tensile sample. In other words, the significant differences in scale will substantially increase time for solidification, leading to coarse, macro segregation. As a slab solidifies, enrichment of the liquid preceding the dendrite growth leads to increased segregation between dendrite arms. Owing to the very slow solidification rate in thick slabs compared with the rapid solidification in small tensile samples, the secondary dendrite arm spacing is much coarser in slabs and thus, the segregation pattern and microstructures formed are different. 

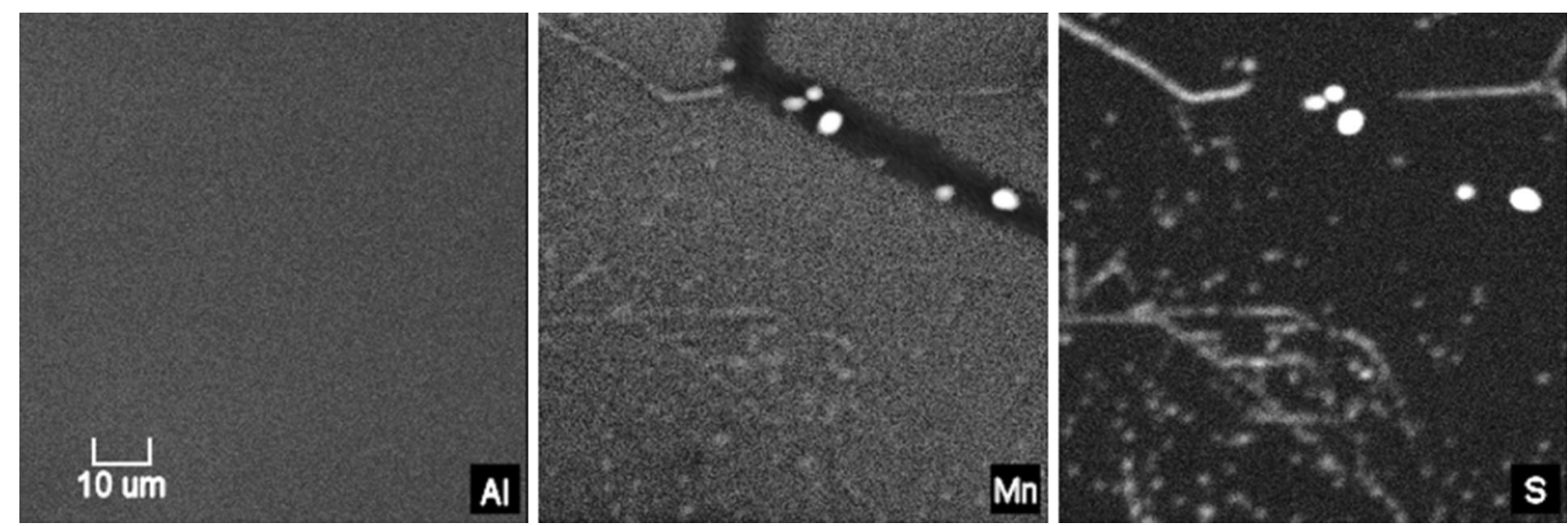

Fig. 10-EPMA image: Higher magnification of Fig. 9; C1 in situ Melt condition, held for 10 min at $1273 \mathrm{~K}\left(1000{ }^{\circ} \mathrm{C}\right)$, and then quenched.

A solidifying strand is also subject to ferrostatic pressure which, in conjunction with the strand alternating between caster rolls, causes fluid flow in the liquid that can "wash away" the tips of advancing dendrites, further enhancing segregation. It is known that $\mathrm{MnS}$ precipitates in segregated areas, such as between dendrite arms in continuously cast slabs, leading to significant precipitation within austenite grains and decreasing the availability of $\mathrm{S}$ to segregate to austenite grain boundaries, which would be beneficial for hot ductility. On the other hand, in small cylindrical specimens for hot ductility testing, the finer solidification pattern leads to reduced segregation, less precipitation of $\mathrm{MnS}$, and therefore increased availability for $\mathrm{S}$ to segregate to austenite grain boundaries.

\section{CONCLUSIONS}

Hot ductility testing was performed on low carbon steels with a range of $\mathrm{Mn} / \mathrm{S}$ ratios at a low strain rate of $7.5 \times 10^{-4} \mathrm{~s}^{-1}$. Solution treatment, in situ melting, and isothermal holding patterns were performed to establish the effect of thermal history and $\mathrm{Mn} / \mathrm{S}$ ratio on hot ductility. The results obtained were as follows:

1. At less than the $\mathrm{Ae}_{3}$ temperature, steels, $\mathrm{C} 1, \mathrm{C} 2$, and C3 showed ductility troughs for both solution treatment and in situ melting conditions because of transformation controlled intergranular failure along thin films of ferrite at prior austenite boundaries, where $\mathrm{MnS}$ precipitation within these films enhanced the failure mechanism.

2. At greater than the $\mathrm{Ae}_{3}$ temperature, steel $\mathrm{C} 3$ showed excellent ductility, while the low C, low Mn steels, C1 and $\mathrm{C} 2$, exhibited a wide and deep ductility trough, because of intergranular grain boundary failure via grain boundary sliding, enhanced by precipitation of $\mathrm{MnS}$ at austenite grain boundaries.

3. Isothermal holding at $1273 \mathrm{~K}\left(1000{ }^{\circ} \mathrm{C}\right)$ for $10 \mathrm{~min}$ utes, before tensile testing, substantially improved hot ductility for the steel $\mathrm{C} 1$ because of coarsening of $\mathrm{MnS}$ at austenite grain boundaries as identified by EPMA.
4. Steel C4 showed good ductility at all test temperatures for solution treatment tests because of grain refinement caused by the $\mathrm{Nb}$ and $\mathrm{Ti}$ microalloying additions. For in situ melting conditions, this grainrefinement ability was lost and ductility was significantly lower because of the detrimental effects of large grain size combined with fine microalloyed precipitates.

5. The commercial production of steels $\mathrm{C} 1$ and $\mathrm{C} 2$ do not have any cracking issues during continuous casting, contrary to indications from hot ductility simulations. This discrepancy appears to be because of a marked difference in precipitation behavior because of the oversimplification of the thermal history for the hot ductility test program. A simplified hot ductility test was found to be inadequate for investigating the potential of low $\mathrm{C}$, low Mn steels to develop transverse cracking, and it is recommended that future experiments are conducted using detailed simulations of the thermal history during continuous casting.

\section{ACKNOWLEDGMENTS}

The current study was conducted at the University of Wollongong under a funding support from BlueScope Steel, Australia. The authors wish to thank Mr. Les Moore for conducting the EPMA analysis and assisting with interpretation of the results.

\section{REFERENCES}

1. T. Gladman: The Physical Metallurgical of Microalloyed Steels, The Institute of Materials, London, 1997, p. 312.

2. A. Cowley and B. Mintz: Mater. Sci. Technol., 2004, vol. 20, pp. 1431-39.

3. B. Mintz and Z. Mohamed: Mater. Sci. Technol., 1989, vol. 5 (12), pp. $1212-19$

4. B. Mintz, S. Yue, and J.J. Jonas: Int. Mater. Rev., 1991, vol. 36 (5), pp. $187-217$.

5. B. Mintz and R. Abushosha: Mater. Sci. Technol., 1992, vol. 8 (2), pp. 171-77. 
6. R. Abushosha, S. Ayyad, and B. Mintz: Mater. Sci. Technol., 1998, vol. 14 (3), pp. 227-35.

7. B. Mintz: ISIJ Int., 1999, vol. 39 (3), pp. 833-55.

8. B. Mintz and J. R. Banerjee: Mater. Sci. Technol 2010, vol. 26 (5), pp. 547-551.

9. H. Kabayashi: ISIJ Int., 1991, vol. 31 (3), pp. 268-77.

10. M. Suzuki, C.H. Yu, H. Shibata, and T. Emi: ISIJ Int., 1997, vol. 37 (9), pp. 862-71.

11. K. Yasumoto, Y. Maehara, S. Ura, and Y. Ohmori: Mater. Sci. Technol., 1985, vol. 1 (2), pp. 111-16.

12. B. Mintz, R. Abushosha, O.G. Comineli, and M.A. Loyola de Oliveira: THERMEC'97: International Conference on Thermomechanical Processing of Steels \& Other Materials, Wollongong, 1997, pp. 867-73.

13. Y. Maehara, K. Yasumoto, H. Tomono, T. Nagamichi, and Y. Ohmori: Mater. Sci. Technol., 1990, vol. 6 (9), pp. 793-806.

14. K.M. Banks, A. Tuling, and B. Mintz: Mater. Sci. Technol., 2012, vol. 28 (5), pp. 536-42.

15. B. Mintz, J.M. Stewart, and D.N. Crowther: Trans. Iron Steel Inst. Jpn., 1987, vol. 27, pp. 959-64.

16. A.M. El-wazri, F. Hassani, S. Yue, and E. Es-sadiqi: Iron Steelmak, 1998, vol. 1, pp. 37-41.
17. A.M. El-wazri, F. Hassani, S. Yue, E. Es-sadiqi, L.E. Collins, and K. Iqbal: ISIJ Int., 1999, vol. 39 (3), pp. 253-62.

18. S. Akhlaghi, F. Hassani, and S. Yue: 40th MWSP Conf. Proc., pp. 699-705, Pittsburgh, PA, ISS., Oct 25-28, 1998.

19. K.W. Andrews: J. Iron Steel Inst., 1965, vol. 203, pp. 721-29.

20. C. Chimani, G.X. Shan, K. Morwald, O. Kolendnik, H.J. Bohm, D. Duschlbauer, and T. Drabek: AISTech 2006 Proceedings, vol 1, pp. 825-830, AIST, Warrendale, PA, May 1-5, 2006.

21. Y. Maehara and T. Nagamichi: Mater. Sci. Technol., 1991, vol. 7 (10), pp. 915-21.

22. K. Carpenter: Ph.D. Thesis, Faculty of Engineering, University of Wollongong, NSW, 1994.

23. A. Mannucci, E. Anelli, M. Armengol, and M. Vedani: MSF, 2010, vols. 638-642, pp. 3362-67.

24. Y. Gao and K. Sorimachi: ISIJ Int., 1995, vol. 35 (7), pp. 914 19.

25. E.T. Turkdogan, S. Ignatowicz, and J. Pearson: J. Iron Steel Inst., 1955, vol. 180 , p. 349.

26. X. Tsekouras: Private Communication, BlueScope Steel, Five Islands Road, Port Kembla, NSW, 2010. 